\title{
Assessment of the quantitative and chemical groundwater status of the Lukowica river catchment area
}

\author{
Damian Pietrzak \\ AGH University of Science and Technology, Faculty of Geology, Geophysics and Environmental Protection; \\ al. A. Mickiewicza 30,30-059 Krakow, Poland; e-mail: pietrzak.damian1@gmail.com
}

(C) 2016 Authors. This is an open access publication, which can be used, distributed and reproduced in any medium according to the Creative Commons CC-BY 4.0 License requiring that the original work has been properly cited.

The main objective of this thesis is the assessment of the quantitative and chemical groundwater and surface water status of the Łukowica river catchment area. This area is located within the Magura Nappe of Outer Carpathians that are built of flysch, which is a series of alternating layers of sandstone and shale (Oszczypko \& Wójcik 1989a, 1989b). The reason for making hydrological characteristics of the catchment area is i.e. to determine the status and causes of hydrological changes occurring within it, using the surface and groundwater, management, the degree of anthropogenic impact on the water, quantitative and chemical balance of water and the size of disposable and renewable resources of analyzed area. Hydrological investigations are necessary to know the process of water circulation in the catchment area. Then these investigations were the basis for further works focused on the factors affecting features of the river regime. The work is based on my own field researches carried out in September 2015. In order to assess the quantitative and chemical waters status, hydrogeological mappings of the field were performed, including measurements of the depth of groundwater table in dug wells by hydrogeological whistle. The discharge of sources and the volume flow of the river in the upper, middle and lower section, and two inflows was also examined. Flow measurements for the river were made on the 10 meter-section by float method. For the inflows, the volumetric method was applied (Banach 2005). At the end, the literature and cartographic elaborations were collected. Prepared materials enabled to make the hydrogeological map of the quaternary multiaquifer formation and to illustrate the circulation of groundwater. On these basis the groundwater's renewable and disposable resources of the catchment basin were calculated (Chełmicki 2001) and they are $3086 \mathrm{~m}^{3} / \mathrm{d}$ and $1543 \mathrm{~m}^{3} / \mathrm{d}$ respectively. To determine the amount of reserves of groundwater resources it is necessary to compare obtained results with an average annual extraction from groundwater intakes (Rozporzadzenie..., 2008). For the purpose of the work the water samples were collected in 7 dug wells and in 4 points alongside the river - in the upper, middle and lower section. The samples were analyzed in the Accredited Hydrogeochemical Laboratory of the Hydrogeology and Engineering Geology Department AGH (Accreditation Certificate AB 1050). The test results were the basis for assessing the chemical status of water. They are developed in accordance with applicable laws, which are based on the Water Framework Directive of the European Parliament (Commission Directive..., 2009) and Regulation of the Minister of the Environment for the criteria and method of evaluation of groundwater status (Rozporzadzenie..., 2015). The mineralization of the surface water of Łukowica River is more or less constant at the entire length and it is $430-450 \mathrm{mg} / \mathrm{dm}^{3}$, whereas the mineralization of groundwater for the catchment is more $\mathrm{di}$ verse and ranges from $325 \mathrm{mg} / \mathrm{dm}^{3}$ to $553 \mathrm{mg} / \mathrm{dm}^{3}$. 
According to the Shchukarev-Priklonskiy classification, both surface water and groundwater are $\mathrm{HCO}_{3}-\mathrm{Ca}-\mathrm{Mg}$ type. On the basis of the results of chemical analyzes, the chemical status of groundwater was considered as good, since they were classified as class II of groundwater quality (Rozporzadzenie..., 2015). The limit values for class I have been exceeded for the following cations: $\mathrm{Zn}^{2+}, \mathrm{Cu}^{2+}, \mathrm{Mo}^{6+}, \mathrm{Ag}^{+}, \mathrm{Ca}^{2+}$ and anions: $\mathrm{NO}_{2}^{-}$ and $\mathrm{HCO}_{3}^{-}$. The chemical status of surface water was considered as good, since it was classified as class II of surface water quality (Rozporzadzenie..., 2011). The limit values for I class have been exceeded only for anion $\mathrm{HCO}_{3}^{-}$.

All European Union countries, including Poland, are obliged to respect the Water Framework Directive, established by the European Parliament in 2000 and updated in 2009 (Commission Directive..., 2009). It obliges member states to perform i.e. assessment of quantitative and chemical status in an area of separated bodies of groundwater. Result of the assessment of the quantitative and chemical groundwater status is the basis for the development of action programs. These programs lead to protection of groundwater bodies and to achieve good groundwater status at the latest by 2015. Many catchments of small streams have not been covered by such tests so far, hence the appropriateness of conducting the studies mentioned above.

Summing up, both surface water and groundwater of the Łukowica River catchment area were classified into class II of water quality, what means that they are characterized by a good chemical status. Mineralization of surface water is similar on the entire length of the river and is $430-450 \mathrm{mg} / \mathrm{dm}^{3}$. In contrast, mineralization of groundwater is in the range from $325 \mathrm{mg} / \mathrm{dm}^{3}$ to $553 \mathrm{mg} / \mathrm{dm}^{3}$. The amount of renewable resources for this catchment is $3086 \mathrm{~m}^{3} / \mathrm{d}$ and the value of disposable resources is $1543 \mathrm{~m}^{3} / \mathrm{d}$.

\section{REFERENCES}

Banach W., 2005. Strona modułu Hydrologia i hydromechanika. 7. Materiały. Materiały pomocnicze doćwiczeń.Pomiary objętości przepływu. [on-line:] http://holmes.iigw.pl/ $\sim$ wbanach/dydaktyka/hydrologia_inf/materialy.php [access: 9 February 2016].

Chełmicki W., 2001. Woda: zasoby, degradacja, ochrona. Wyd. Naukowe PWN, Warszawa.

Commission Directive 2009/90/EC of 31 July 2009 laying down, pursuant to Directive 2000/60/EC of the European Parliament and of the Council, technical specifications for chemical analysis and monitoring of water status.

Oszczypko N. \& Wójcik A., 1989a. Mapa geologiczna Polski w skali 1:50 000. Arkusz Łącko (1034) i arkusz Nowy Sącz (1035). Państwowy Instytut Geologiczny, Warszawa.

Oszczypko N. \& Wójcik A., 1989b. Objaśnienia do Mapy geologicznej Polski w skali 1:50 000. Arkusz Łącko (1034) $i$ arkusz Nowy Sącz (1035). Państwowy Instytut Geologiczny, Warszawa.

Rozporządzenie Ministra Środowiska $z$ dnia 23 lipca 2008 r. w sprawie kryteriów i sposobu oceny stanu wód podziemnych. Dz. U. 2008, nr 143, poz. 896.

Rozporządzenie Ministra Środowiska $z$ dnia 9 listopada 2011 r. w sprawie sposobu klasyfikacji stanu jednolitych części wód powierzchniowych oraz środowiskowych norm jakości dla substancji priorytetowych. Dz.U. 2005, nr 239, poz. 2019.

Rozporządzenie Ministra Środowiska $z$ dnia 21 grudnia 2015 r. w sprawie kryteriów i sposobu oceny stanu jednolitych części wód podziemnych. Dz.U. 2015, poz. 469. 